\title{
Article 24. Non-Parties
}

The Parties shall encourage non-Parties to adhere to this Protocol and to contribute appropriate information to the Access and Benefit-sharing Clearing-House.

Article 24 is a short provision on how Parties to the Nagoya Protocol are to relate to non-Parties. As a general rule, treaties do not create obligations or rights for third Parties:' that is, a treaty 'cannot, by its own force, impose an obligation on a third State nor modify in any way the legal rights of a third State without its consent.'2 Nonetheless, a treaty may affect non-Parties. This provision, therefore, clarifies how non-Parties may be affected by the Protocol in their dealings with Parties.

Article 24 creates a two-fold obligation. First, it mandates Parties to encourage (i.e., at least to remove barriers to, and/or create incentives for) ${ }^{3}$ nonParties to comply with the Protocol on a voluntary basis, which may include encouragement to become Parties to the Protocol. In doing so, the Protocol leaves considerable flexibility as to the means to fulfill this provision. So, Parties may provide technical, financial or institutional support for adherence to the Protocol. ${ }^{4}$ Bilateral trade and cooperation agreements, ${ }^{5}$ or unilateral trade-incentive schemes could also include commitments to become Parties to the Protocol. ${ }^{6}$ Second, the provision mandates Parties to encourage non-

1 VClt, Article 30. See also Anthony Aust, Modern Treaty Law and Practice (Cambridge: Cambridge University Press, 2007), chapter 14.

2 Ibid., 256.

3 On the obligation to encourage, see this commentary on Article 9, section 1.

4 For a comparable discussion in the context of the Biosafety Protocol, see Mackenzie et al., Explanatory Guide to the Cartagena Protocol, op. cit., 157.

5 See this commentary on Article 4, section 3.

6 The EU, for instance, uses trade incentives to encourage other States become Parties to other multilateral environmental agreements in its bilateral trade and development agreements with third countries: see Gracia Marín Durán and Elisa Morgera, Environmental Integration in the EU'S External Relations: Beyond Multilateral Dimensions (Oxford: Hart Publishing, 2012); and Rok Žvelc, "Environmental Integration in EU Trade Policy: The Generalised System of Preferences, Trade Sustainability Impact Assessments and Free Trade Agreements," in The External Environmental Policy of the European Union: EU and International Law Perspectives, ed. Elisa Morgera (Cambridge: Cambridge University Press, 2012), 174. 
Parties to provide information on a voluntary basis to the ABs Clearinghouse, ${ }^{7}$ which aims to gather as much relevant information as possible on ABs to make it available to all Parties. ${ }^{8}$

Article 24 is partially modeled on the Biosafety Protocol, ${ }^{9}$ with a view to discouraging the development of conflicting national practices related to ABS and preventing non-Parties from developing a competitive trade advantage by remaining outside the international ABs regime. ${ }^{10}$ As opposed to the Cartagena Protocol, however, the Nagoya Protocol does not specify the type of information that could be provided by non-Parties to the ABs Clearinghouse. ${ }^{11}$

Negotiators considered, and decided against, a proposal ${ }^{12}$ fully modeled after the Cartagena Protocol, ${ }^{13}$ to create an additional obligation for Parties to ensure that ABs activities and transactions related to genetic resources and derivatives with non-Parties be consistent with the Protocol and the Convention. ${ }^{14}$ Such a proposal would not have required 'precise accordance' with the Protocol's detailed provisions. ${ }^{15}$ The proposal was in line with practice in other multilateral environmental agreements to create a strong incentive for non-Parties to become Parties to a treaty. ${ }^{16}$ Negotiators eventually drew inspiration only from the 'softest part' of the corresponding provisions in the Cartagena Protocol, in line with a general approach to avoid any frictions

$7 \quad$ See this commentary on Article 14, section 3.

8 Mackenzie et al., Explanatory Guide to the Cartagena Protocol, op. cit., 157.

9 Biosafety Protocol Article 24(2).

$10 \quad$ Mackenzie et al., Explanatory Guide to the Cartagena Protocol, op. cit., 157.

11 An earlier draft of this provision specified that such information would specifically concern activities and transactions regarding access and benefit-sharing related to genetic resources and derivatives within non-Parties' jurisdiction: Montreal II Draft, draft article 18 ter (2).

12 As had been requested, for instance by the African Group. See ENB, "Summary of the Ninth Meeting of the Working Group on Access and Benefit-sharing of the Convention on Biological Diversity: 22-28 March 2010," Vol. 9 no. 503, 31 March 2010, 9.

13 Biosafety Protocol Article 24(1), which requires that import/export of living modified organisms between Parties and non-Parties be consistent with at least the objective of the Protocol.

14 Montreal II Draft, draft article 18 ter.

15 Along the lines of the interpretation of the corresponding provision in the Biosafety Protocol: see Mackenzie et al., Explanatory Guide to the Cartagena Protocol, op. cit., 153.

16 Ibid., 154. The Montreal Protocol and the Basel Convention prohibit trade with nonParties unless it is conducted according to specific conditions which ensure minimum standards equivalent to those established in the treaties, while CITEs sets the conditions under which trade with non-Parties can be undertaken. 
between the Nagoya Protocol and wTo law. ${ }^{17}$ As a result, Article 24 has been considered a 'very weak provision' when compared to other multilateral environmental agreements. ${ }^{18}$ This is particularly significant as the United States, who is not a Party to the $\mathrm{CBD}^{19}$ and therefore quite unlikely to become a Party to the Protocol, represents 40 percent of the global biotech sector ${ }^{20}$ and in addition has significant ex situ collections. ${ }^{21}$ In all events, free-riding by nonParties may be tackled by provider countries' domestic ABs frameworks providing more favorable access conditions to users from Parties to the Protocol or countries that have put in place comparable measures. ${ }^{22}$

Finally, it should be recalled that СвD Parties that will not become Parties to the Protocol remain bound by relevant $\mathrm{CBD}$ requirements on $\mathrm{ABs} .^{23}$

17 Pavoni, "Nagoya Protocol and wTo Law," op. cit., 190 and 196.

18 Ibid., 196.

19 As the Protocol can only be signed and ratified by СвD parties: see Nagoya Protocol Article 32, and this commentary on final clauses, section 2.

$20 \quad$ Oberthür and Rosendal, "Conclusions," op. cit., 234.

21 See FAO, The Second Report on the State of the World Plant Genetic Resources for Food and Agriculture, op. cit., chapter 3.

22 As discussed in this commentary on Article 6, section 5.2.

23 Notably свр Article 15. Glowka, Burhenne-Guilmin and Synge, Guide to the Convention on Biological Diversity, op. cit., 124. For similar considerations in relation to the Biosafety Protocol, see Mackenzie et al., Explanatory Guide to the Cartagena Protocol, op. cit., 153. 